\title{
ÍNDICE DE ILUSTRACIONES
}

1. Grabado de Theodor de Bry que apareció en la traducción flamenca de fines del xvi de la Brevísima relación de Las Casas........

2. Portada de la traducción realizada por Thomas Nicholls de la Historia del descubrimiento y conquista de la provincia del Perú de Agustín de Zárate.

3. Mapa Drake-Mellon

4. Mapa del cartógrafo holandés Jodocus Hondius que describe la circunnavegación de Francis Drake (1577-1580) y la de Thomas Cavendish (1586-1588)

5. Grabado que muestra a un nativo de Nova Albión colocando una corona de plumas en la cabeza de sir Francis Drake.

6. Grabado que muestra a sir Francis Drake vestido con una armadura mientras supervisa la carga de una embarcación

7. Mapamundi de Nicola van Sype

8. Mapamundi de Edward Wright ............................................................. 135

9. Mapamundi de Abraham Ortelius ..................................................... 137

10. Portada de la primera edición de La Dragontea (1598).................... 185

11. Descripción de la Audiencia de Panamá ............................................. 211

12. Portada de la Historia general del Perú (1617) del Inca Garcilaso de la Vega 
